\title{
SALMONELLA HADAR PHAGE TYPES ISOLATED FROM DIFFERENT SOURCES OF FOODCHAIN IN BRAZIL
}

\author{
Christiane Soares Pereira*; Márcia Torres Nunes de Almeida; Márcia Lima Festivo; Renata Garcia Costa; \\ Eliane Moura Falavina dos Reis; Dália dos Prazeres Rodrigues
}

Laboratório de Referência Nacional de Cólera e Enteroinfecções Bacterianas, Departamento de Bacteriologia, Instituto Oswaldo Cruz, Fundação Oswaldo Cruz, Rio de Janeiro, RJ, Brasil

Submitted: May 17, 2007; Approved: September 09, 2007.

\begin{abstract}
The gastroenteritis incidence caused by Salmonella Hadar has increased over the last decades worldwide. The uncontrolled use of antimicrobials for treating human patients and veterinary field contributes to increase the multidrug resistance of this serovar. In the present investigation, a total of $179 \mathrm{~S}$. Hadar isolates from different sources of foodchain in Brazil were phage typed and analyzed for their antimicrobial resistance profile. The main $S$. Hadar phage types isolated were PT 38, PT 39, PT 40, PT 11, PT 34, PT 1 and PT 22. Others phage types as PT 13, PT 19, PT 21, PT 23, PT 31, PT 33 and PT 37 were obtained in low percentages. A total of $35,7 \% \mathrm{~S}$. Hadar strains were resistant to two or more antimicrobials drugs. Furthermore, no resistance to third generation cephalosporin or ciprofloxacin was identified in these strains. Those results appoint to $S$. Hadar phage types circulating among animals, food and humans, as well as the increasing of multidrug resistance. The surveillance and monitoring of $S$. Hadar strains based on phage typing and antimicrobial resistance profile are useful for detecting outbreaks, identifying sources of infection and implementing prevention and control measures of salmonellosis.
\end{abstract}

Key words: Salmonella Hadar, Phage Types, Foodchain, Multidrug resistance

\section{INTRODUCTION}

Salmonella is recognized as an important pathogen to public health and notified as cause of bacterial diarrhea around the world. Some serotypes are usually associated with a self-limited disease or outbreaks of gastroenteritis in humans (9).

An important characteristic of this serovar is the emergence of resistance to multiple antimicrobial agents that increased the rates of morbidity and mortality for infections with resistant strains (10). The cause of rapid spread of multidrug resistance bacteria is increased due many factors such as the abusive use and uncontrolled sale of antimicrobials in activities related with agriculture, veterinary and human treatments. This fact may be complex especially when bad hygiene is applied in foodchain at industries, restaurants or even at home (8).
During the last two decades, Salmonella Hadar has become the second commonest serotype isolated from foodborne disease in European countries (11). Often, the outbreaks caused by these serovar are associated with food of animal origin as meat and poultry products (1). Currently Salmonella Hadar phage typing has enabled differentiation into 35 phage types and PT 2 appear with high prevalence in some geographical areas $(2,3)$.

The objective of this study was to evaluate the prevalence of phage types of Salmonella Hadar isolated from different sources in Brazil and its correspondent multidrug resistance profiles.

\section{MATERIALAND METHODS}

Bacterial strains - The strains studied were obtained from the Brazilian Salmonella enterica collection of the LRNCEB.

\footnotetext{
*Corresponding Author. Mailing address: Laboratório de Referência Nacional de Cólera e Enteroinfecções Bacterianas, Laboratório de EnterobactériasDepto. de Bacteriologia - Instituto Oswaldo Cruz - FIOCRUZ - Avenida Brasil, 4365, Manguinhos, Rio de Janeiro, RJ. Pavilhão Rocha Lima - $3^{\circ}$ andar - sala 320. CEP: 21040-360. E-mail: chrisspm@ioc.fiocruz.br
} 
These strains had been collected in the period from January to December of 2005 and were selected on the basis of their different isolation sources and geographical origins. Then, a total of 179 strains were identified by standard methods. Serological typing was performed by the slide agglutination method using LRNCEB prepared antisera.

Phage Typing - The phage types (PTs) of 179 Salmonella Hadar isolates were determined using the phage typing scheme preconized by De Sa et al. (5), the phage set was provided by the WHO Reference Centre for phage typing (Colindale, London, UK).

Antimicrobial Susceptibility Testing - The antimicrobial susceptibility was determined using a disc diffusion method using Mueller-Hinton agar. The 12 antibiotics (from Oxoid, UK) used for the tests were Ampicillin $10 \mu \mathrm{g}$ (AMP), Chloramphenicol $30 \mu \mathrm{g}$ (CHL), Tetracycline $30 \mu \mathrm{g}$ (TCY), Cefoxitin $30 \mu \mathrm{g}$ (FOX), Ceftriaxone $30 \mu \mathrm{g}$ (CRO), Cyprofloxacin $5 \mu \mathrm{g}$ (CIP), Gentamicin $10 \mu \mathrm{g}$ (GEN), Imipenem $10 \mu \mathrm{g}$ (IMP), Nalidixic Acid $30 \mu \mathrm{g}$ (NAL), Trimethoprim/Sulfamethoxazole $1.25 \mu \mathrm{g} / 23.75 \mu \mathrm{g}$ (SXT), Nitrofurantoin $300 \mu \mathrm{g}$ (NIT) and Cephalotin $30 \mu \mathrm{g}$ (CEP). The disc diffusion method and the interpretation of results were performed as described on the Clinical and Laboratory Standards Institute guidelines (4). Multidrug-resistance was defined as resistance to three or more classes of antimicrobials.

\section{RESULTS}

The Salmonella Hadar strains were differentiated into 14 phage types and the most common were PT 39 (57\%) and PT 38 (26\%) followed by PT 40 (4.5\%), PT 11 (3.5\%), PT 34 (2\%), PT 1 $(1.6 \%)$ and PT $22(1 \%)$. Also, other phage types were obtained in lower percentages: PT 13, PT 19, PT 21, PT 23, PT 31, PT 33 and PT 37 as showed in Table 1.

Among the $179 \mathrm{~S}$. Hadar strains analyzed for phage typing were evaluated to antimicrobial resistance and $35.7 \%$ were resistant to two or more antimicrobials drugs. The main phage

Table 1. Salmonella Hadar phage types isolated from different sources at LABENT/IOC/FIOCRUZ, Brazil, 2005.

\begin{tabular}{cccc}
\hline Phage Type & $\mathrm{N}(\%)$ & Phage Type & $\mathrm{N}(\%)$ \\
\hline PT 39 & $102(57)$ & PT 13 & $1(0.5)$ \\
PT 38 & $47(26)$ & PT 19 & $1(0.5)$ \\
PT 40 & $8(4.5)$ & PT 21 & $1(0.5)$ \\
PT 11 & $6(3.5)$ & PT 23 & $1(0.5)$ \\
PT 34 & $4(2)$ & PT 31 & $1(0.5)$ \\
PT 1 & $3(1.6)$ & PT 33 & $1(0.5)$ \\
PT 22 & $2(1)$ & PT 37 & $1(0.5)$ \\
\hline
\end{tabular}

$\mathrm{N}=$ Number of Salmonella Hadar strains, $\%=$ Percentage from the total S.Hadar strains (179). types isolated were PT 39 and PT 38 that showed characteristics to multiple antibiotic resistances in more than three antimicrobial classes but no resistance to third generation cephalosporin or ciprofloxacin. The frequency of resistance to individual drugs and multiple resistances according to the $S$. Hadar phage type is shown in Table 2. Some $S$. Hadar phage types isolates as PT 39 (6), PT 38 (6), PT 34 (1) and PT 11 (1) presented sensitivity to all drugs tested.

The Salmonella Hadar phage types have been isolated from environment (61), food (55), foodstuffs (34) and animal origin (28) and their distribution is shown in Table 3.

Table 2. Salmonella Hadar phage types isolated from different sources at LABENT/IOC/FIOCRUZ, Brazil, and their antimicrobial profile.

\begin{tabular}{ccc}
\hline $\begin{array}{c}\text { Phage } \\
\text { Type }\end{array}$ & $\begin{array}{c}\text { Antimicrobial } \\
\text { Profile }\end{array}$ & $\begin{array}{c}\text { Source } \\
(\mathrm{N})\end{array}$ \\
\hline PT39 & TCY & EN (3), AN (1) FS (1), \\
& Food (1) \\
& TCY-NAL & Food (1), EN (3), AN (1) \\
& TCY-NIT & EN (1), Food (1), AN (1) \\
& TCY-FOX & EN (1) \\
& TCY-GEN-NAL & EN (1) \\
& TCY-NAL-SXT-NIT & EN(1) \\
& TCY-GEN-NAL-NIT & Food (1) \\
& CHL-NIT & Food (1) \\
& CHL-TCY-NAL & FN(1) \\
PT 38 & NIT & Food (1) \\
& TCY-SXT & EN (3) Food (2) \\
& TCY-NAL & AN (1) \\
& TCY-NAL-NIT & AN (1) \\
& TCY-GEN-NAL-NIT & AN (1) \\
& TCY-CEP-NAL-NIT & Food (1) \\
& AMP-TCY-NIT & EN (2) \\
PT 11 & TCY-NAL & EN (1) \\
PT 1 & TCY-NAL &
\end{tabular}

$\mathrm{N}=$ Number of Salmonella Hadar isolated according to source; $\mathrm{AN}=$ animal source; $\mathrm{EN}=$ environmental source; $\mathrm{FS}=$ Foodstuffs; $\mathrm{AMP}=$ Ampicilin $; \mathrm{CEP}=$ Cephalotin; $\mathrm{CHL}=$ Chloramphenicol; $\mathrm{FOX}=$ Cephoxitin; GEN= Gentamicin; NAL= Nalidixic Acid; NIT= Nitrofurantoin; $\mathrm{SXT}=$ Trimethoprim/Sulfamethoxazole; $\mathrm{TCY}=$ Tetracycline.

\section{DISCUSSION}

In the present investigation the presence of Salmonella Hadar phage types isolated from animals, food for human consumption and their association to multidrug resistance 
Table 3. Distribution of Salmonella Hadar Phage Types isolated according to their sources during 2005 at LRNCEB/IOC/ FIOCRUZ, Brazil.

\begin{tabular}{cccccc}
\hline Phage & \multicolumn{5}{c}{ Sources } \\
\cline { 2 - 6 } Types & FS & Food & AN & EN & US \\
\hline PT 39 & 24 & 32 & 15 & 31 & - \\
PT 38 & 4 & 17 & 5 & 21 & - \\
PT 11 & - & - & 2 & 4 & \\
PT 40 & 4 & 1 & 1 & 2 & - \\
PT 34 & 1 & 1 & 1 & 1 & - \\
PT 1 & - & 1 & 2 & - & - \\
PT 22 & - & 1 & - & 1 & \\
PT 13 & - & 1 & - & - & - \\
PT 19 & - & - & - & 1 & - \\
PT 21 & 1 & - & - & - & - \\
PT 23 & - & - & 1 & - & - \\
PT 31 & - & 1 & - & - & - \\
PT 33 & - & - & 1 & - & - \\
PT 37 & - & - & - & - & 1 \\
\hline Total & $\mathbf{3 4}$ & $\mathbf{5 5}$ & $\mathbf{2 8}$ & $\mathbf{6 1}$ & $\mathbf{1}$ \\
\hline
\end{tabular}

$\mathrm{FS}=$ Foodstuffs source; $\mathrm{AN}=$ animal source; $\mathrm{EN}=$ environmental source; $\mathrm{US}=$ unrelated source.

appoint to the need of monitoring activities in order to minimize the spread of this serovar in Brazil (8).

Although our findings did not indicate the human source, the diversity of phage types isolated shows the rapid spread of Salmonella Hadar in Brazil. Also, we observed a geographical distribution of $S$. Hadar phage types in South and South-east regions probably associated to the proximity to poultry industries $(9,10)$.

In Brazil, phage typing distinguished serotype Hadar variants in 14 different phage types. Among them a high prevalence of resistant strains was detected to PT 39 and PT 38. Researches developed in Italy described the occurrence of phage types PT 26, PT 1, PT 3 and PT 2 isolated from human and animal sources. Several studies appoint to other phage types as PT 9 and PT 10 in Belgique and PT 2 and PT 10 in Canada isolated from humans $(2,3,6,7)$.

The methods used shown to be an efficient epidemiological tool, especially because of the rarity of $S$. Hadar isolation. Moreover, the antimicrobial susceptibility test showed the resistance to tetracycline in addition to nalidixic acid and other drugs such as gentamicin that represents epidemiological markers. Others studies supposed that the widespread use of antimicrobials in veterinary medicine may contribute to increase the resistance of pathogens to humans. Furthermore, the diversification of phage types results is probably associated with bacteria acquiring phage restricting plasmids or temperate phages $(9,12)$.

The emergence of phage types associated to multidrug resistance is a potential public health risk due to the zoonotic nature of human salmonelosis. The surveillance of $S$. Hadar strains based on these methods are useful for implementing prevention and control measures to sanitary vigilance authorities $(13,14)$.

\section{RESUMO}

\section{Fagotipos de Salmonella Hadar isolados de diferentes fontes da cadeia alimentar no Brasil}

A incidência de gastrenterite causada por Salmonella Hadar tem aumentado ao longo dos anos em todo o mundo. $\mathrm{O}$ uso indiscriminado de antimicrobianos na clínica humana e veterinária tem contribuído para o aumento da multiresistência deste sorovar. No presente estudo, 179 cepas de $S$. Hadar isoladas de diferentes fontes da cadeia alimentar no Brasil foram fagotipadas e analisadas quanto ao perfil de resistência antimicrobiana. Os principais fagotipos de $S$. Hadar isolados foram PT 38, PT 39, PT 40, PT 11, PT 34, PT 1 e PT 22. Outros fagotipos como PT 13, PT 19, PT 21, PT 23, PT 31, PT 33 e PT 37 foram obtidos em menores percentagens. Um total de $35,7 \%$ das cepas avaliadas foi resistente a dois ou mais antimicrobianos. Por outro lado, não foi observada resistência a cefalosporinas de terceira geração ou ciprofloxacina. Esses resultados apontam para a circulação de fagotipos de $S$. Hadar entre animais, alimentos e seres humanos, bem como o aumento da multiresistência antimicrobiana. O monitoramento de cepas de $S$. Hadar baseado na fagotipagem e no padrão de resistência aos antimicrobianos são ferramentas úteis na detecção de surtos, identificação das fontes de infecção, além de auxiliar na implantação de programas de controle e prevenção de salmoneloses.

Palavras-chaves: Salmonella Hadar, Fagotipos, Cadeia alimentar, Resistência Antimicrobiana

\section{REFERENCES}

1. Bisbini, P.; Leoni, E.; Nanetti, A. (2000). An outbreak of Salmonella Hadar associated with roast rabbit in a restaurant. Eur. J. Epidemiol., 16: 613-618.

2. CCDR - Canadian Integrated Surveillance Report for 1995 on Salmonella, Campylobacter and Pathogenic Escherichia coli. (1998). Can. Commun. Dis. Rep., 24S5.

3. CNRSS - Donnés de surveillance du Centre National de Référence des Salmonella et Shigella, Belgique 2002. (2002). Centre National de Référence des Salmonella et Shigella.

4. CLSI. (2006). Clinical and Laboratories Standards Institute. Performance standards for antimicrobial susceptibility testing M100S16, Wayne (PA), CLSI. 
5. De Sá, J.D.H.; Ward, R.L.; Rowe, B. (1980). A scheme for the phagetyping of Salmonella Hadar. FEMS Microbiol. Lett., 9: 175177.

6. Fantasia, M.; Paglietti, B.; Filetici, E.; Anastásio, M.P.; Rubino, S. (1997). Conventional and molecular approaches to isolates of Salmonella hadar from sporadic and epidemic cases. J. Appl. Microbiol., 82: 494-498.

7. Faustini, A.; Sangalli, M.; Fantasia, M.; Manganello, R.; Mattaccini, E.; Trippanera, R.; Spera, D.; La Rosa, U.; Topi, M.T.; Forastiere, F.; Perucci, C.A. (1998). An outbreak of Salmonella hadar associated with food consumption at a building site canteen. Eur. J. Epidemiol., 14: 99-106, 1998.

8. Pereira, C.S.; Medeiros, L.M.; Costa, R.G.; Festivo, M.L.; Reis, E.M.F.; Seki, L.M.; Rodrigues, D.P. (2007). Phage Typing and Multdidrug resistance profile in $S$.Typhimurium isolated from different sources in Brazil from 1999 to 2004. Braz. J. Microbiol., 38: 385-390.

9. Polo, F.; Figueras, M.J.; Inza, I.; Sala, J.; Fleisher, J.M.; Guarro, J. (1999). Prevalence of Salmonella serotypes in environmental waters and their relationships with indicator organisms. Antonie von Leeuwenhoek, 75: 285-292.
10. Ribeiro, A.R.; Kellermann, A.; Santos, L.R.; Fittél, A.P.; Nascimento, V.P. (2006). Resistência Antimicrobiana em Salmonella enterica subsp. enterica sorovar Hadar isoladas de carcaças de frango. Arq. Inst. Biol., 73: 357-360.

11. Rowe, B.; Hall, M.L.M.; Ward, L.R.; De Sa, J.D.H. (1980). Epidemic spread of Salmonella hadar in England and Wales. Br. Med. J., 280: $1065-1066$

12. Soler, P.; González-Sanz, R.; Bleda, M.J.; Hernández, G.; Echeíta, A.; Usera, M.A. (2006). Antimicrobial resistance in non-typhoidal Salmonella from human sources, Spain, 2001-2003. J. Antimicrob. Chemother, 58: 310-314.

13. Valdezate, S.; Echeíta, A.; Díez, R.; Usera, M.A. (2000). Evaluation of Phenotypic and Genotypic Markers for Characterization of de emerging gastroenteritis Pathogen Salmonella hadar. Eur. J. Clin. Microbiol. Infect. Dis., 19: 275-281.

14. Weide-Botjes, M.; Kobe, B.; Lange, C.; Schwarz, S. (1998). Molecular typing of Salmonella enterica subsp. enterica serovar Hadar: evaluation and application of different typing methods. Vet. Microbiol., 61: 215-227. 